$9-1990$

\title{
Ancient channels of the Susquehanna River beneath Chesapeake Bay and the Delmarva Peninsula
}

\author{
Steven M. Colman \\ Jeffrey P. Halka \\ C. Hobbs \\ Virginia Institute of Marine Science \\ Robert B. Mixon \\ David S. Foster
}

Follow this and additional works at: https://scholarworks.wm.edu/vimsarticles

Part of the Geology Commons

\section{Recommended Citation}

Colman, Steven M.; Halka, Jeffrey P.; Hobbs, C.; Mixon, Robert B.; and Foster, David S., Ancient channels of the Susquehanna River beneath Chesapeake Bay and the Delmarva Peninsula (1990). Geological Society of America Bulletin, 102, 1268-1279. doi:10.1130/0016-7606(1990)102 2.3.CO;2

This Article is brought to you for free and open access by the Virginia Institute of Marine Science at W\&M ScholarWorks. It has been accepted for inclusion in VIMS Articles by an authorized administrator of W\&M ScholarWorks. For more information, please contact scholarworks@wm.edu. 


\title{
Ancient channels of the Susquehanna River beneath Chesapeake Bay and the Delmarva Peninsula
}

\author{
STEVEN M. COLMAN U.S. Geological Survey, Woods Hole, Massachusetts 02543 \\ JEFFREY P. HALKA Maryland Geological Survey, 2300 St. Paul St, Baltimore, Maryland 21218 \\ C. H. HOBBS III Virginia Institute of Marine Science, Gloucester Point, Virginia 23062 \\ ROBERT B. MIXON U.S. Geological Survey, 926 National Center, Reston, Virginia 22092 \\ DAVID S. FOSTER U.S. Geological Survey, Woods Hole, Massachusetts 02543
}

\section{ABSTRACT}

Three generations of the ancestral Susquehanna River system have been mapped beneath Chesapeake Bay and the southern Delmarva Peninsula. Closely spaced seismic reflection profiles in the bay and boreholes in the bay and on the southern Delmarva Peninsula allow detailed reconstruction of each paleochannel system. The channel systems were formed during glacial low sea-level stands, and each contains a channel-fill sequence that records the subsequent transgression. The trunk channels of each system are 2 to $4 \mathrm{~km}$ wide and are incised 30 to $50 \mathrm{~m}$ into underlying strata; they have irregular longitudinal profiles and very low gradients within the Chesapeake Bay area.

The three main-stem channels diverge from the head of the bay toward the southeast. The channels are rarely coincident, although they commonly intersect. All three main channels pass beneath the southern Delmarva Peninsula, forming an age progression from north (oldest) to south (youngest) beneath the Peninsula, and from east (oldest) to west (youngest) beneath Chesapeake Bay. Southward progradation of the tip of the Delmarva Peninsula during interglacial high sea-level stands caused southward migration of the mouth of the bay, so that the next generation of channels were incised progressively further towards the southwest.

The youngest paleochannel is clearly of late Wisconsinan age, about $18 \mathrm{ka}$, and the intermediate one appears to be late Illinoian in age, or about $150 \mathrm{ka}$. The age of the oldest paleochannel is not well constrained, but it is in the range of about 200 to $400 \mathrm{ka}$. The three paleochannel systems imply a dynamic coastal-plain environment and at least two previous generations of the Chesapeake Bay.
Both the Chesapeake Bay and the southern Delmarva Peninsula have changed considerably in the past half million years.

\section{INTRODUCTION}

The Chesapeake Bay is the largest estuary in the United States. It is a classic coastal-plain estuary, carved during periods of low relative sea level by fluvial erosion of gently dipping coastal-plain strata; the resulting river valley was drowned during periods of high relative sea level, forming an estuary. The morphology of the Chesapeake Bay, both its coastline and its bathymetry, clearly reflect its origin as a drowned river valley (Fig. 1), at least to a first approximation (Colman and others, 1988).

During the last major glaciation and low sealevel stand, about 18 to $20 \mathrm{ka}$, sea level dropped to at least $-85 \mathrm{~m}$ on the mid-Atlantic continental shelf (Dillon and Oldale, 1978; Bloom, 1983). During this time, the area occupied by the Chesapeake Bay was subaerially exposed, and a narrow, steep-walled valley was incised into the Coastal Plain strata by the Susquehanna River system and its major tributary, the Potomac River. As sea level rose during the late Pleistocene and Holocene, the fluvial valley was transformed first into a restricted river estuary and then into the modern open-bay estuary (Colman and Hobbs, 1987, 1988; Colman and Halka, 1989a, 1989b). This transgression is continuing today and has partially filled the former fluvial channel with estuarine sediments. Because the advance and retreat of continental ice sheets (and hence sea-level rise and fall) have been cyclic for the past 0.75 m.y. or so (Hays and others, 1976), with a first-order period of about $100,000 \mathrm{yr}$, the Susquehanna River system should have carved multiple generations of channels beneath Chesapeake Bay.

The history of the last cycle of sea level in the
Chesapeake Bay area is relatively well understood and, because it is only partly filled, the location of the late Pleistocene fluvial channel is known in much of the bay (Ryan, 1953; Hack, 1957; Harrison and others, 1965). In addition, several scattered segments of paleochannels have previously been identified beneath the Chesapeake Bay and the Delmarva Peninsula, most recently by Mixon (1985). Prior to our study, however, the main part of the Chesapeake Bay had not been completely surveyed using seismic reflection methods. Consequently, relatively little was known about the regional geographic and temporal pattern of the paleochannels that were the precursors to the late Pleistocene fluvial channels in the bay. In a previous paper, we identified three generations of fluvial channels beneath the bay and the Delmarva Peninsula (Colman and Mixon, 1988); here we synthesize their geographic pattern, discuss their origin and preservation, summarize what is known about their ages, and discuss the implications of these data for both the long-term evolution of the bay and for its future.

\section{PREVIOUS WORK}

The morphology and bathymetry of Chesapeake Bay, especially its intricate, dendritic tributary pattern and its prominent central channel, have long suggested that a relict fluvial drainage system exists buried beneath the sediments of the bay. The fact that sea level was considerably lower than present during Pleistocene glaciations supports this speculation. Ryan (1953) first documented a major fluvial channel beneath the bay, on the basis of the borings taken across the main part of the bay for the Annapolis-Kent Island Bridge (Fig. 2), where the channel bottom occurs at a depth of about $-61 \mathrm{~m}(-200 \mathrm{ft})$. In addition to the detailed cross section of the channel reconstructed from the borings, Ryan

Geological Society of America Bulletin, v. 102, p. 1268-1279, 11 figs., September 1990. 


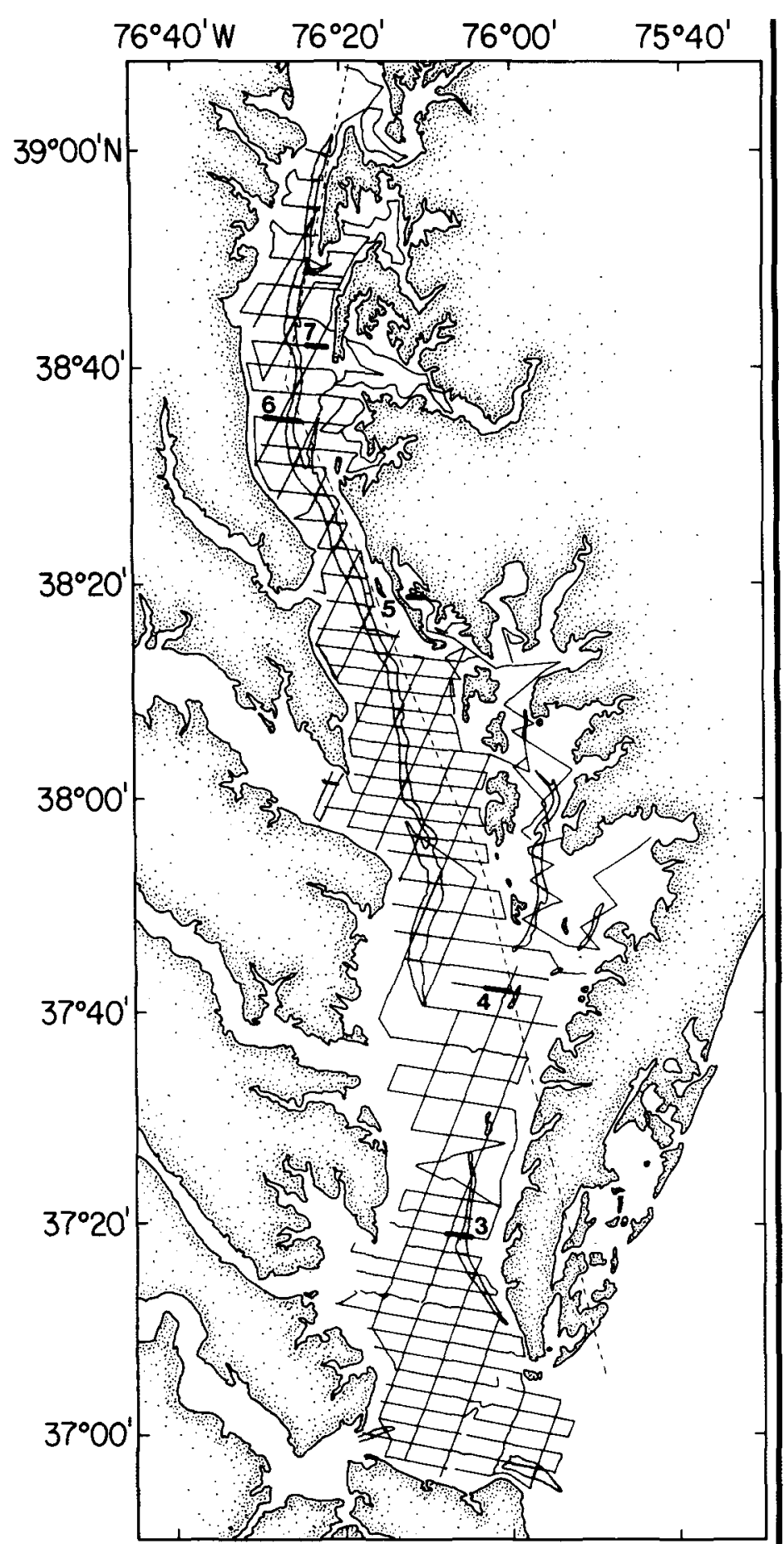

0 $20 \mathrm{~km}$

\section{0} $10 \mathrm{nmi}$

Figure 1. Map of the Chesapeake Bay showing tracklines of seismic reflection profiles and locations of profiles shown in Figures 3-7 (thick, numbered sections). Line of profile for Figure 10 is shown as a dashed line. Areas with water depths greater than $18.3 \mathrm{~m}$ (60 ft) are shaded.

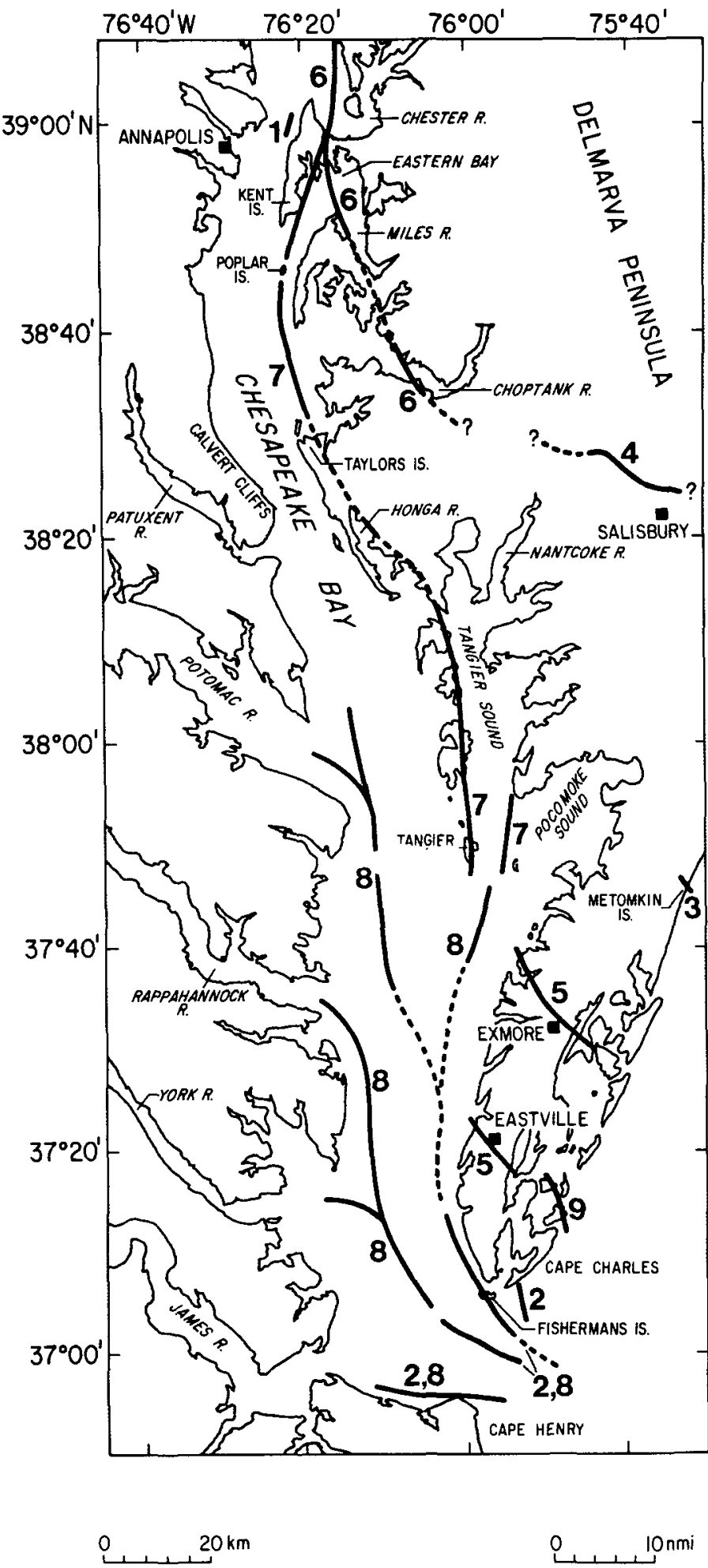

Figure 2. Map of the Chesapeake Bay showing geographic names mentioned in the text and the locations of previously identified or inferred paleochannels, referenced by number: 1, Ryan, 1953, Hack, 1957; 2, Harrison and others, 1965, Meisburger, 1972; 3, Harrison, 1972; 4, Hansen, 1966, Weigle, 1972; 5, Mixon, 1985; 6, Schubel and Zabawa, 1973; 7, Kehrin and others, 1980; 8, Carron, 1979; 9, Shideler and others, 1984. 
(1953) projected the longitudinal profile of the channel for the length of the bay, and he calculated the degree to which the ancient valley was filled, using the projected channel for the base of the fill. According to his projection, the fluvial channel was predicted to be at a depth of about $-91 \mathrm{~m}(-300 \mathrm{ft})$ at the bay mouth. Hack (1957) used the logs for the Kent Island Bridge and for bridges over tributary drainages to describe the fluvial and estuarine fills of the buried valleys. He was the first to suggest the existence of more than one generation of fill, and, therefore, more than one age of fluvial channel. He also attempted to reconstruct the profiles of the fluvial system downstream from the Annapolis-Kent Island Bridge and estimated that the base of the main fluvial channel at the bay mouth should be at a depth of about $-112 \mathrm{~m}(-370 \mathrm{ft})$.

Harrison and others (1965) described the configuration of the bay-mouth area based on the borings for the Chesapeake Bay Bridge-Tunnel (Fig. 2) and on some of the first seismic reflection profiles obtained in the bay. The deepest fluvial channel found in either the BridgeTunnel borings or in the seismic reflection profiles was at a depth of about $-49 \mathrm{~m}(-160 \mathrm{ft})$. Harrison and others (1965) proposed that a minimum of $12 \mathrm{~m}$ ( $40 \mathrm{ft}$ ) of uplift had occurred in the bay-mouth area since the fluvial channel was formed in late Wisconsinan (latest Pleistocene) time to account for the difference between the depth of the channel at the Annapolis-Kent Island Bridge ( $-61 \mathrm{~m},-200 \mathrm{ft})$ and that at the bay mouth $(-49 \mathrm{~m},-160 \mathrm{ft})$, assuming no gradient. Using Hack's (1957) projected channel gradient, Harrison and others (1965) suggested a minimum of $52 \mathrm{~m}$ (170 ft) of uplift.

Harrison and others (1965) argued against the possibility that the late Wisconsinan channel of the Susquehanna River crossed the Delmarva Peninsula north of the bay mouth. Harrison (1972), however, suggested that an ancestral channel of the Potomac or the combined Potomac-Susquehanna system, possibly of late Wisconsinan age, crossed the Delmarva Peninsula near Metomkin Island (Fig. 2), on the basis of the distribution of reworked crystalline gravel along the modern beach.

Wells drilled on the Delmarva Peninsula have revealed a deep $(-61 \mathrm{~m} ;-200 \mathrm{ft})$ channel just south of the southwest corner of Delaware, called the "Naylor Mill" or "Salisbury" channel (Fig. 2). Hansen (1966) first described this channel, and suggested that it was a fluvial channel cut during the low sea-level stand of the Illinoian Glaciation. The extent of the channel, however, is problematic. Although the thalweg of the channel has been traced over a length of about $33 \mathrm{~km}$ (20 mi), efforts to define its full extent have been difficult. The base of the channel rises abruptly east of Salisbury (Weigle, 1972). It rises more gently to the west, but it is at an altitude greater than $-24 \mathrm{~m}(-80 \mathrm{ft})$ just west of the Nanticoke River (Fig. 2).

On the southern Delmarva Peninsula, Mixon (1985) used geologic mapping and borehole data to identify two major paleochannels (Fig. 2) and to describe the stratigraphic relations between the fluvial-estuarine fills of the channels and the overlying barrier-spit complexes. The southern channel, near the town of Eastville, reaches depths of at least $-61 \mathrm{~m}(-200 \mathrm{ft})$, whereas the northern channel, near the town of Exmore, was thought to reach depths of only $-21 \mathrm{~m}(-70 \mathrm{ft})$. Later drilling showed that the northern channel also reached depths of about $-61 \mathrm{~m}$ ( $-200 \mathrm{ft}$ ) (R. B. Mixon and D. S. Powars, 1986, unpub. data; Colman and Mixon, 1988). Both channels clearly cross from the bay beneath the Delmarva Peninsula and head oceanward beneath the continental shelf.

A number of studies have identified segments of paleochannels in the Chesapeake Bay area using seismic reflection methods. Schubel and
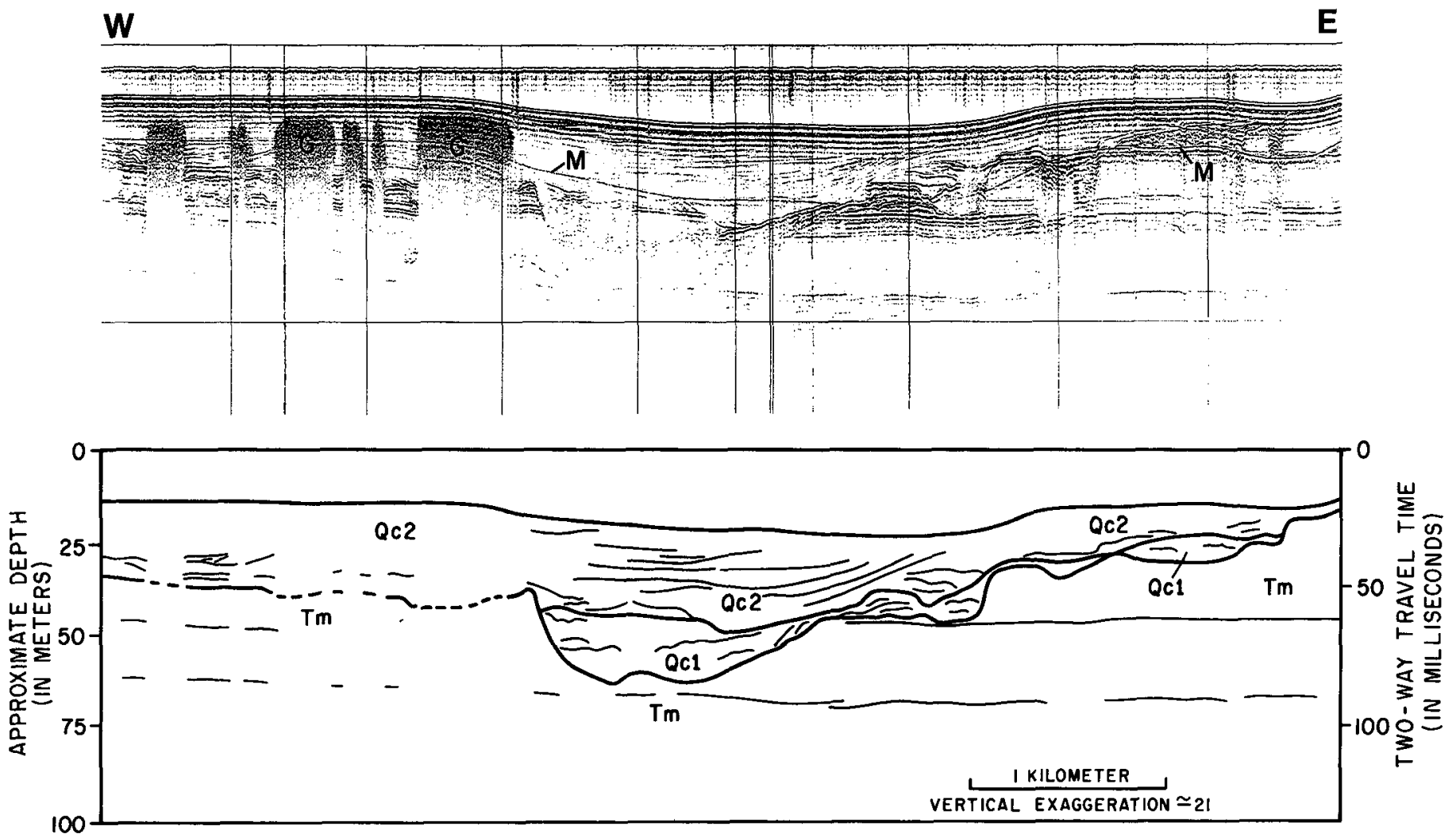

Figure 3. Seismic reflection profile and interpretive cross section of the Cape Charles paleochannel. Location shown in Figure 1. Depth scale assumes a speed of sound in water and sediments of $1.5 \mathrm{~km} / \mathrm{s}$. M, multiple reflection; G, reflections obscured by gas in sediments; Tm, late Tertiary marine sediments; Qc1 and Qc2, basal and upper units of the fill of the Cape Charles paleochannel. 

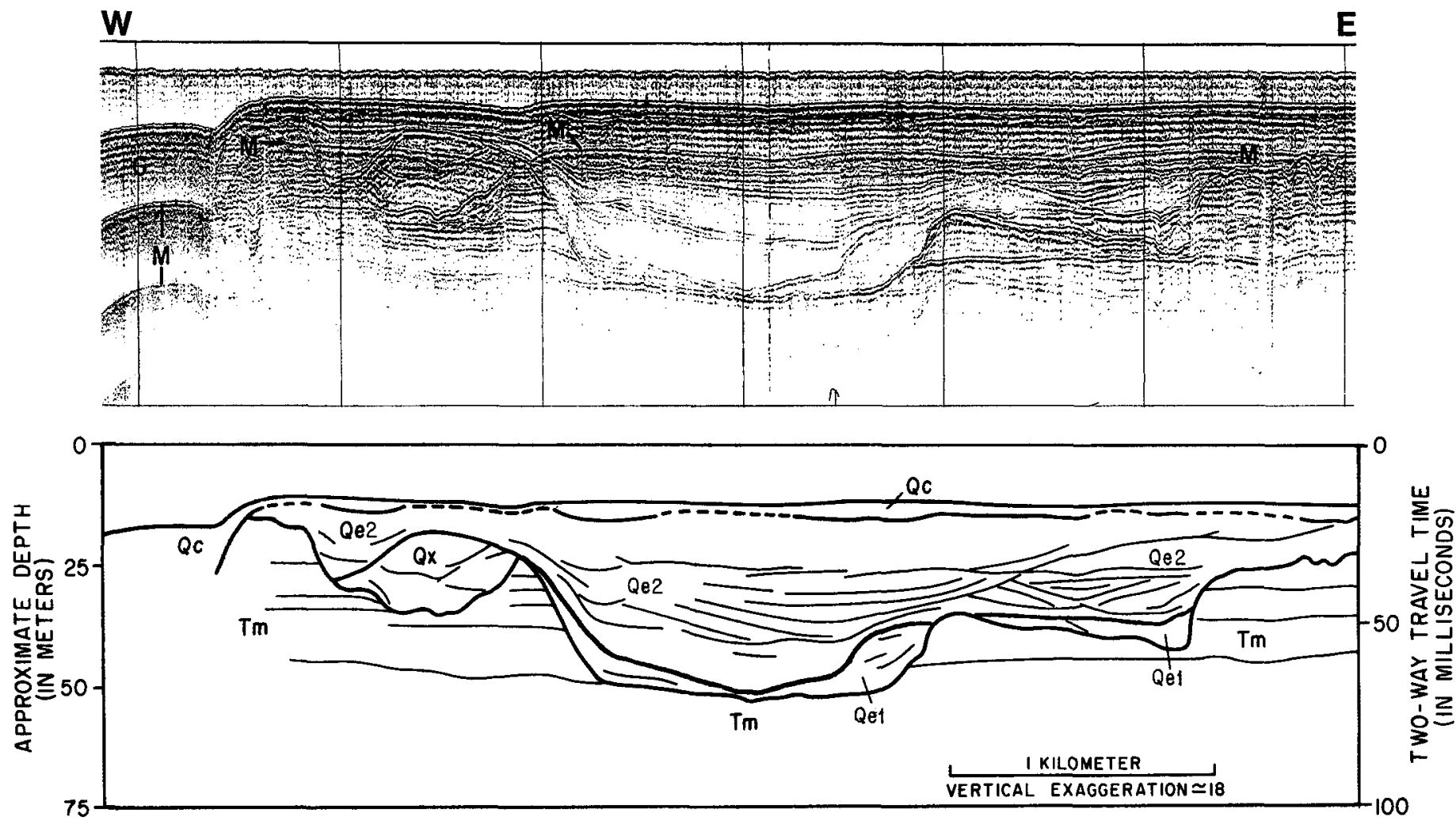

Figure 4. Seismic reflection profile and interpretive cross section of the Eastville paleochannel. Location shown in Figure 1. Depth scale assumes a speed of sound in water and sediments of $1.5 \mathrm{~km} / \mathrm{s}$. M, multiple reflection; $\mathrm{G}$, reflections obscured by gas in sediments; Tm, late Tertiary marine sediments; Qc, undifferentiated sediments correlative with the fill of the Cape Charles paleochannel; Qe1 and Qe2, basal and upper units of the fill of the Eastville paleochannel; Qx, undifferentiated sediments correlative with the fill of the Exmore paleochannel.

Zabawa (1973) identified a paleochannel in the lower reaches of the Chester, Miles, and Choptank Rivers (Fig. 2). They suggested that the channel was of Illinoian age and that it turned eastward through the lower Choptank, possibly crossing the Nanticoke River and connecting with the Salisbury paleochannel. Kehrin and others (1980) traced a paleochannel (Fig. 2) from the mouth of Eastern Bay, through the Poplar Island area in the main part of Chesapeake Bay, and into the Taylor Island area. They suggested that this channel (Poplar Island channel) was the same as the one Schubel and Zabawa (1973) identified, and they connected it with one they recognized in Tangier Sound (Tangier Sound channel, Fig. 2). Kehrin and others (1980) agreed with Schubel and Zabawa's (1973) assignment of an Illinoian age for the paleochannel, but they argued that it did not cross the Delmarva Peninsula but instead extended through Tangier Sound and down the eastern side of the main bay.

Carron (1979) collected shallow-penetration, seismic reflection profiles in the Virginia part of the Chesapeake Bay in an attempt to reconstruct the late Wisconsinan drainage system (Fig. 2). He suggested that the combined Rappahannock-
York drainage flowed southward along the west side of the bay, exited the bay area through a paleochannel just northeast of Cape Henry, and joined the Susquehanna system, which flowed down the east side of the bay, out onto the continental shelf. Colman and Hobbs (1987), however, disputed this interpretation and showed that the York River must have flowed eastward from its present mouth to join the Susquehanna well within the area of the present bay.

Shideler and others (1984) identified a major paleochannel beneath the marshes and tidal channels on the east side of the southern Delmarva Peninsula (Fig. 2) using seismic reflection methods. The trend of this channel and the one identified by Mixon (1985) near Eastville appear to be coincident.

\section{DATA AND METHODS}

The Quaternary stratigraphic record in the Chesapeake Bay and the Delmarva Peninsula area comes primarily from three basic types of data: (1) a grid of almost $2,600 \mathrm{~km}$ of shallowpenetration, high-resolution, seismic reflection profiles in the main part of the Chesapeake Bay (Fig. 1); (2) onshore geologic mapping; and
(3) a series of boreholes drilled both onshore and in the bay for engineering work, water wells, and stratigraphic studies.

The seismic reflection data were collected using both boomer-type systems and 3.5- to 5kHz systems (Colman and Hobbs, 1987, 1988; Colman and Halka, 1989a, 1989b). Except as noted, the data shown here were all collected using the boomer system, run at 280 joules and fired at 0.25 - to 0.5 -s intervals. The seismic signals were filtered between $300 \mathrm{~Hz}$ and $5 \mathrm{kHz}$ and recorded at a 0.25 -s sweep rate. Loran-C was used for navigation during the seismic reflection surveys.

Results of recent detailed surficial geologic mapping and descriptions of boreholes for the southern Delmarva Peninsula have been published by Mixon (1985). Additional unpublished core data were used to refine the locations and depths of the ancient channels of the Susquehanna River beneath the Delmarva Peninsula (Colman and Mixon, 1988). Borehole data for the bay itself are concentrated along the bridge and tunnel crossings (Ryan, 1953; Hack, 1957; Harrison and others, 1965) and in locations near the bay mouth (Meisburger, 1972; Colman and Hobbs, 1987). 

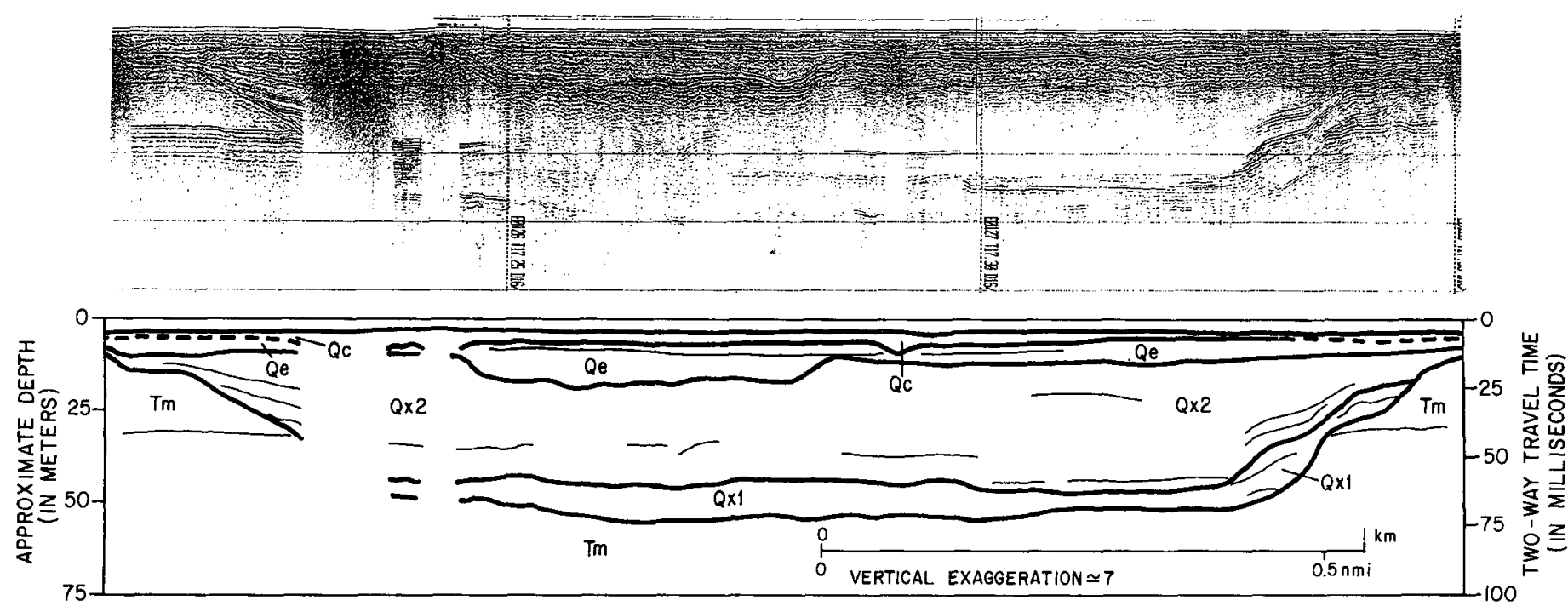

Figure 5. Seismic reflection profile and interpretive cross section of the Exmore paleochannel. Location shown in Figure 1. Depth scale assumes a speed of sound in water and sediments of $1.5 \mathrm{~km} / \mathrm{s}$. M, multiple reflection; Tm, late Tertiary marine sediments; Qc, undifferentiated sediments correlative with the fill of the Cape Charles paleochannel; Qe, undifferentiated sediments correlative with the fill of the Eastville, paleochannel; Qx1 and Qx2, basal and upper units of the fill of the Exmore paleochannel.

\section{STRATIGRAPHY AND MAPPING OF THE PALEOCHANNELS}

The Quaternary stratigraphy beneath the Chesapeake Bay is dominated by paleochannels that were cut by the Susquehanna River and its tributaries into the underlying Tertiary marine deposits, and by the sediments that fill those channels (Figs. 3, 4, and 5). We have identified three distinct generations of these paleochannel systems, which we informally call the "Cape Charles," the "Eastville," and the "Exmore" paleochannels, in order of increasing age. All three channels cross beneath the southern Delmarva
Peninsula, and each is named for a geographic feature on the peninsula.

Seismic reflection and borehole stratigraphic data clearly show that the three paleochannel systems are of different ages and that the sediments that fill them are separated by significant unconformities. The courses of the paleochan-
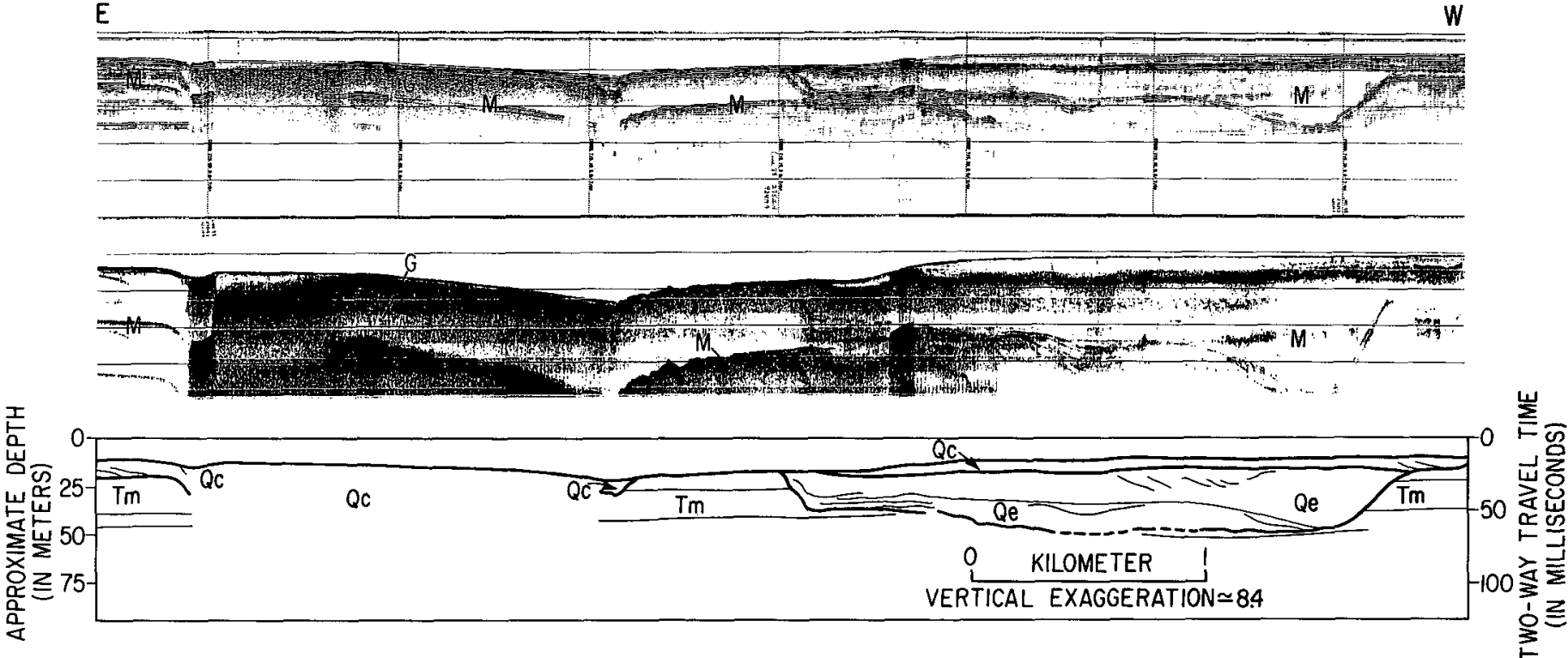

Figure 6. Seismic reflection profiles (upper, boomer; lower, $5 \mathrm{kHz}$ ) and interpretive line drawing of the boomer profile. Profiles show the main stem of the Eastville paleochannel (fill = Qe) adjacent to that of the Cape Charles paleochannel, whose fill (Qc) is obscured by biogenic gas. A clear unconformity separates the fill of the Eastville paleochannel from overlying deposits equivalent to the fill of the Cape Charles paleochannel. Location shown in Figure 1. Depth scale for boomer profile assumes a speed of sound in water and sediments of $1.5 \mathrm{~km} / \mathrm{s}$; vertical scale of the 5-kHz profile is half that of the boomer profile. M, multiple reflection; G, biogenic gas; Tm, late Tertiary marine sediments. 
$\mathbf{E}$
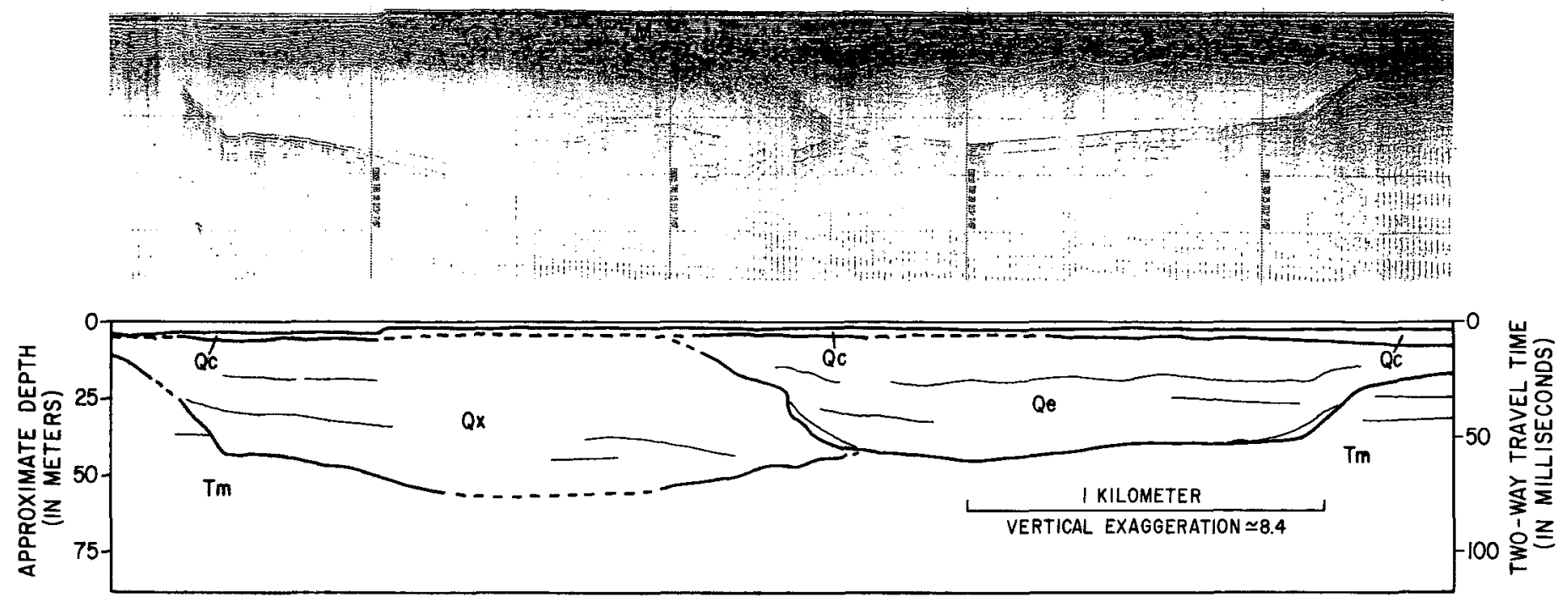

Figure 7. Seismic reflection profile and interpretive line drawing of a cross section showing the main stem of the Eastville paleochannel (fill = Qe) truncating that of the Exmore paleochannel (fill = Qx). Overlying both of these are thin sediments equivalent to the fill of the Cape Charles paleochannel $(Q c)$. Location shown in Figure 1. Depth scale assumes a speed of sound in water and sediments of $1.5 \mathrm{~km} / \mathrm{s}$. $\mathrm{M}$, multiple reflection; Tm, late Tertiary marine sediments.

nels are rarely coincident, although they commonly intersect. Their relative ages can be determined by map patterns and by crosscutting relationships seen on seismic reflection profiles (Figs. 6, 7). The geometries and fill stratigraphies of the three systems are similar, but projection of their courses across multiple, closely spaced profiles usually allows identification of individual channels in the profiles. The three paleochannel systems have been mapped throughout the bay; their courses projected from the seismic reflection data align with their known positions onshore (Fig. 8).

The paleochannel-fill sequences seen in seismic reflection profiles have been divided into two units whose seismic reflection attributes are distinctly different. The lower unit of each fill is characterized by relatively strong, irregular, discontinuous reflections, whereas the upper unit of each fill is characterized by relatively weak, long, smooth, continuous, gently dipping reflections (Figs. 3, 4, and 5). These seismic characteristics, together with lithologic and paleontologic data from relatively deep boreholes (Harrison and others, 1965; Mixon, 1985), indicate that the lower channel-fill unit of each paleochannel is a fluvial deposit, typically consisting of coarse sand and fine gravel. The upper unit of each paleochannel fill, in contrast, was deposited in river-estuary to open-bay environments or in nearshore-marine environments at the bay mouth. These units are finer grained than the lower, fluvial units, and the lithologies are commonly complex, consisting of interbedded muddy sand, silt, and peat, especially near the bay mouth. The estuarine units become finer grained both landward and toward the tops of the units.

Where the paleochannels underlie present land areas, their structure and fill lithology are known from well logs and stratigraphic boreholes. The Eastville paleochannel is especially well documented where it crosses beneath the Delmarva Peninsula (Fig. 9). Mixon (1985) divided the channel fill into several units based on lithology and texture and showed that on the Delmarva Peninsula the paleochannel is overlain by a barrier-spit complex. The channel geometry and the fill stratigraphy derived from the borehole data are both remarkably similar to those derived from adjacent seismic reflection profiles in the bay.

The channel systems show progressively less relationship to the present configuration of the Chesapeake Bay with age. The Cape Charles paleochannel (the youngest) is confined to the main part of the bay, and for most of its length, underlies the modern bathymetric channel of the bay (Fig. 8). In a few areas inside the bay where Holocene progradation of spits has occurred, however, the modern bathymetric channel is offset from the Cape Charles paleochannel, for example, south of the mouth of the Potomac River (Colman and Hobbs, 1988; Colman and Halka, 1989a). In other areas, Holocene sedimentation rates have been high enough to completely fill the Cape Charles paleochannel with estuarine sediments. An example occurs off the mouth of the Rappahannock River, where there is little bathymetric expression of the location of the former fluvial channel (Fig. 1). More dramatic recent changes have occurred at the mouth of the bay, where progradation of the Delmarva Peninsula and a shoal complex across the mouth of the bay have caused the axial channel of the bay to migrate as much as $12 \mathrm{~km}$ south of its former position above the Cape Charles paleochannel, which passes beneath Fishermans Island (Fig. 2) at the southern tip of the Delmarva Peninsula (Colman and others, 1988). This displaced axial channel of the bay at its mouth is the likely location for incision of the Susquehanna River during the next sea-level fall.

The Eastville paleochannel (the intermediateage channel) is generally located along the eastern margin of the main part of the Chesapeake Bay, although it deviates from this position in several places (Fig. 8). This paleochannel crosses the mouth of the Chester River and passes beneath Kent Island (Fig. 2). It then swings westward, and off the Calvert Cliffs, crosses the younger Cape Charles paleochannel-the only case of an older main-stem channel crossing west of a younger one. The Eastville channel almost directly underlies the Cape Charles channel off the Patuxent River before swinging to the eastern side of the main part of the bay. It makes a sharp eastward turn off the mouth of the Potomac River before turning southward again off Tangier Island. Finally, it turns southeastward and passes beneath the Delmarva 


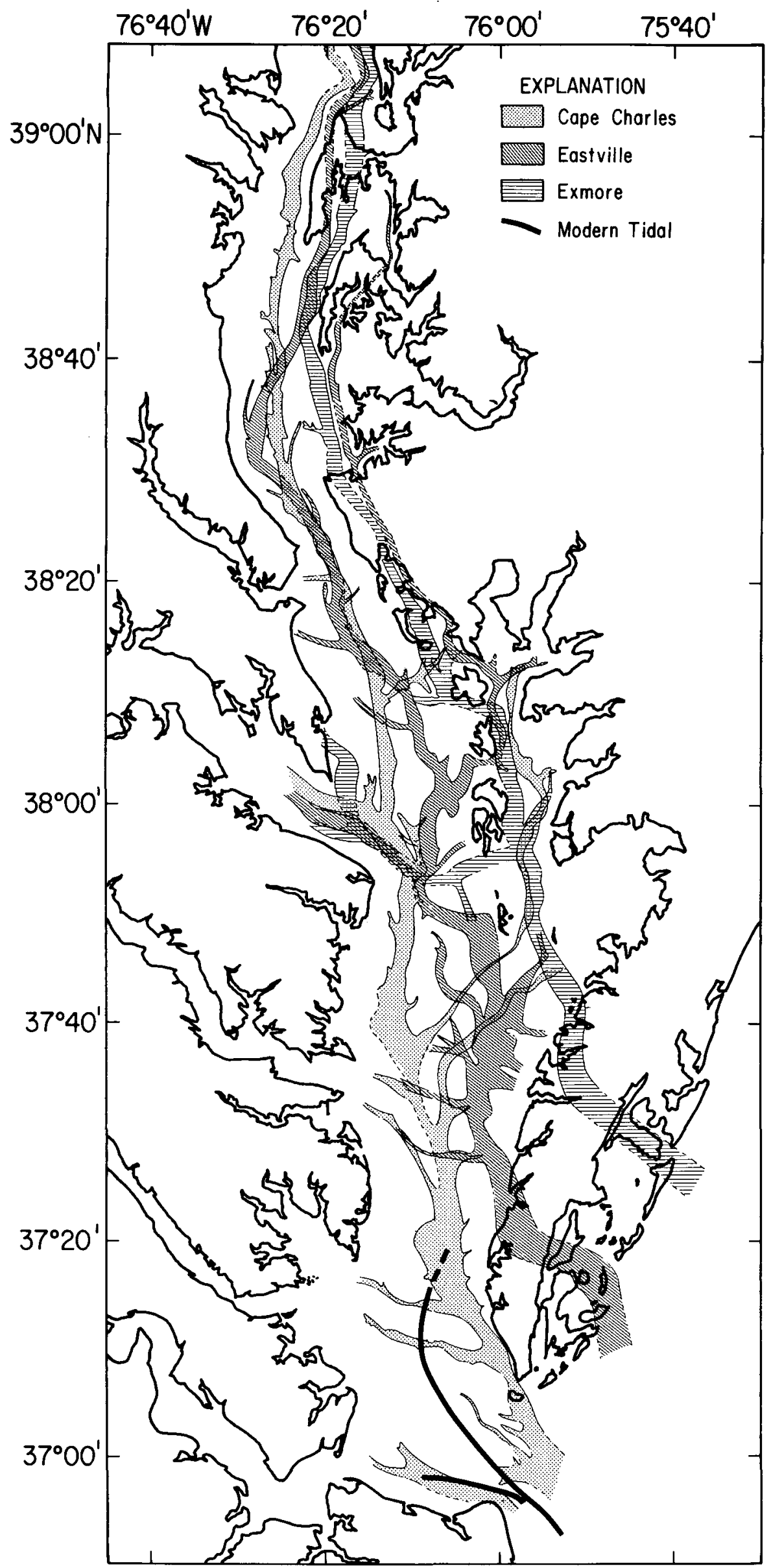

Figure 8. Map of the three major Quaternary paleochannel systems of the Susquehanna River beneath the Chesapeake Bay and the Delmarva Peninsula. The channel margins correspond to the $-\mathbf{3 0} \mathrm{m}$ depth contour on the fluvial unconformities that define the paleochannels. Data compiled from contour maps in Colman and Hobbs (1987, 1988); Colman and Halka (1989a, 1989b); Mixon (1985); and Shideler and others (1984).

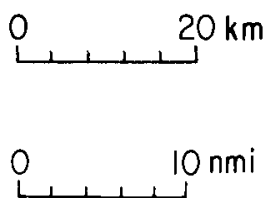


Figure 9. Interpretive cross section, derived from borehole data, of the Eastville paleochannel where it crosses the Delmarva Peninsula. Channel is filled with the fluvialestuarine Stumptown Member of the Nassawadox Formation and is overlain by the barrier-spit sands of the Butlers Bluff Member of the Nassawadox. Modified from Mixon (1985).

Peninsula near the town of Eastville (Mixon, 1985) and emerges beneath the marshes on the eastern side of the peninsula (Shideler and others, 1984).

The Exmore paleochannel (the oldest channel) is everywhere east of the Eastville channel, and for the vast majority of its length, exists entirely outside the main part of Chesapeake Bay (Fig. 8). It crosses the lower part of the Chester River and passes beneath the eastern side of Kent Island (Fig. 2). It then crosses the mouth of Eastern Bay and extends southward beneath the Poplar Island area. Crossing the mouth of the Choptank River, it passes beneath the Taylor Island area and re-emerges beneath the Honga River, following the course of that river southward, eventually entering the upper part of Tangier Sound. It follows the western margin of Tangier Sound before turning southeast and crossing beneath the Delmarva Peninsula near the town of Exmore.

The channels are relatively close together in the northern part of the Chesapeake Bay, but diverge significantly toward the southeast; all three cross beneath the present Delmarva Peninsula. Where they cross the peninsula, the major paleochannels are progressively younger toward the south. The reason for this systematic divergence and southward age progression is discussed in a section below.

\section{CHANNEL DIMENSIONS AND GRADIENTS}

Both the geometry and the stratigraphy of the paleochannel systems indicate that the channels were formed during periods of low sea level when the mouth of the Susquehanna River was far out on the continental shelf. The dimensions of each of the paleochannel systems are similar: the main trunk channel of each system is about 2 to $4 \mathrm{~km}$ wide; each is incised about 30 to $50 \mathrm{~m}$ into the underlying Tertiary strata, to depths of -50 to $-70 \mathrm{~m}$ (Figs. $3-7$ ). The widths of the channels vary but tend to increase slightly downstream (Fig. 8). Longitudinal profiles of the paleochannels derived from seismic reflection profiles and borehole data are irregular (Fig. 10). The over-all gradients of the three

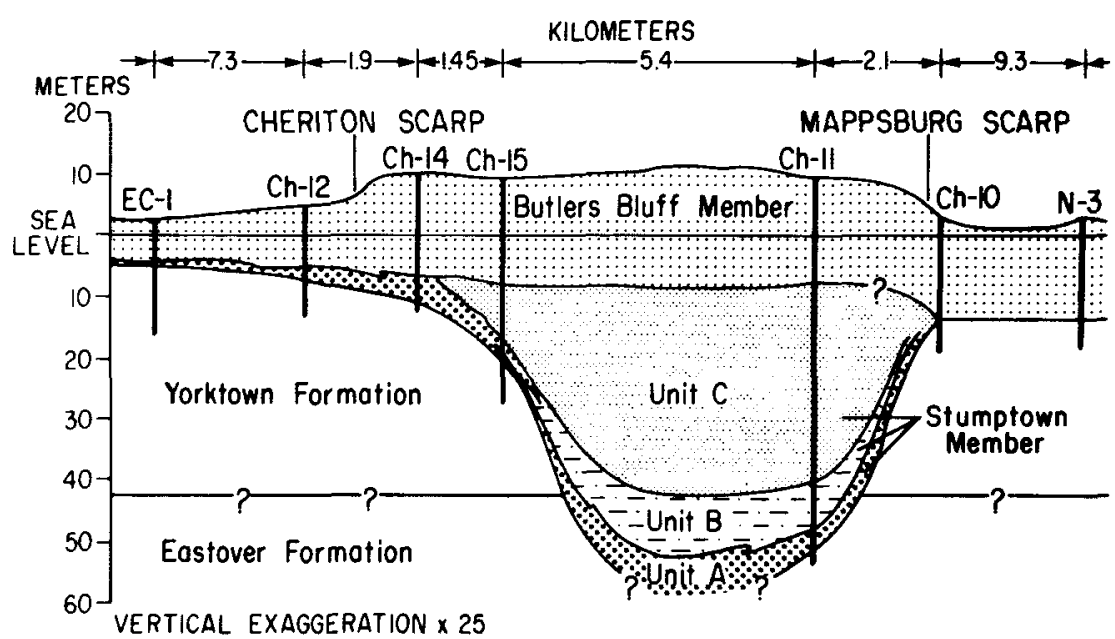

channel systems beneath the bay are similar, but are all unexpectedly low (Fig. 10).

The location of the Cape Charles paleochannel is the best known because of its bathymetric expression and from analysis of seismic reflection data and closely spaced borehole transects that cross it at the mouth of the Susquehanna River, at Kent Island, and at the mouth of the bay. The base of this paleochannel is obscured on some of the seismic reflection profiles by biogenic gas in the channel-fill sediments (Fig. 6; minimum values in Fig. 10A), especially in the middle and upper bay (Halka and others, 1988), so that in these areas the longitudinal profile is not known with certainty. A linear regression of the known basal altitudes of the channel (Fig. 10A) suggests a slight over-all seaward slope of $0.0024 \mathrm{~m} / \mathrm{km}$.

The longitudinal profiles of the Eastville and Exmore paleochannels are well defined by the seismic reflection profiles (Figs. 10B and 10C) because biogenic gas does not occur in the sediments that fill those channels (Halka and others, 1988). The main stems of both channels have irregular profiles that contain closed basins with as much as $10 \mathrm{~m}$ of relief. Linear regressions of the profiles suggest a slightly seaward over-all slope $(0.038 \mathrm{~m} / \mathrm{km})$ for the Eastville channel (Fig. 10B) and a slightly landward over-all slope for the Exmore channel (Fig. 10C), although the latter gradient is probably not significantly different from zero.

The reason for the low channel gradients is not known with certainty. Recent tectonic uplift at the mouth of the bay has been suggested (Harrison and others, 1965), but for reasons that are detailed below, significant uplift now seems unlikely. The range in measurements derived from seismic reflection profiles for the depth to the bases of the channels are similar for the three generations of paleochannels; when plotted together (Fig. 11), they form an overlapping enve- lope of points that define the degree of irregularity in the profiles. The only major source of uncertainty in these measurements is uncertainty in the estimate of sound velocity in the sediments. The velocities used (1,500-1,800 $\mathrm{m} / \mathrm{s}$; Colman and Halka, 1989a, 1989b) yield good correlations with borehole data (Fig. 11) and are probably good to within 10 percent. Three measurements of the depth to the base of the Cape Charles paleochannel are incontrovertible (Fig. 11): (1) $-43 \mathrm{~m}$ at the U.S. 40 bridge at the mouth of the Susquehanna River (Hack, 1957); (2) $-61 \mathrm{~m}$ at the Kent Island Bridge (Hack, 1957); and (3) $-49 \mathrm{~m}$ at the Chesapeake bay (Harrison and others, 1965). Two other borehole points, one for the Exmore and one for the Eastville paleochannel, are thought to be at or near the base of these paleochannels (Mixon, 1985). Hack (1957), without the benefit of the data from the Bridge-Tunnel surveys, suggested a relatively steep fluvial profile in the bay, on the basis of the two upstream bridge crossings. Our data show that this profile is much too steep. Even though the base of the Cape Charles paleochannel is $12 \mathrm{~m}$ deeper at the Kent Island Bridge than it is at the mouth of the bay, $220 \mathrm{~km}$ downstream, the two values appear to be within the range of variation in an irregular bottom profile with a very low average slope (Fig. 11). The water surface above the channel presumably sloped continuously seaward.

During the last major low-sea-level stand, about $18 \mathrm{ka}$, sea level was perhaps at $-85 \mathrm{~m}$ on the mid-Atlantic continental shelf (Dillon and Oldale, 1978). Near the mouth of the bay, the base of the Cape Charles paleochannel is at about $-50 \mathrm{~m}$, and it presumably grades to the lowstand shoreline on the outer continental shelf. If sea level during the last glaciation was at $-85 \mathrm{~m}$ and the mouth of the Susquehanna River was at the edge of the continental shelf, and if Bay Bridge-Tunnel crossing at the mouth of the 

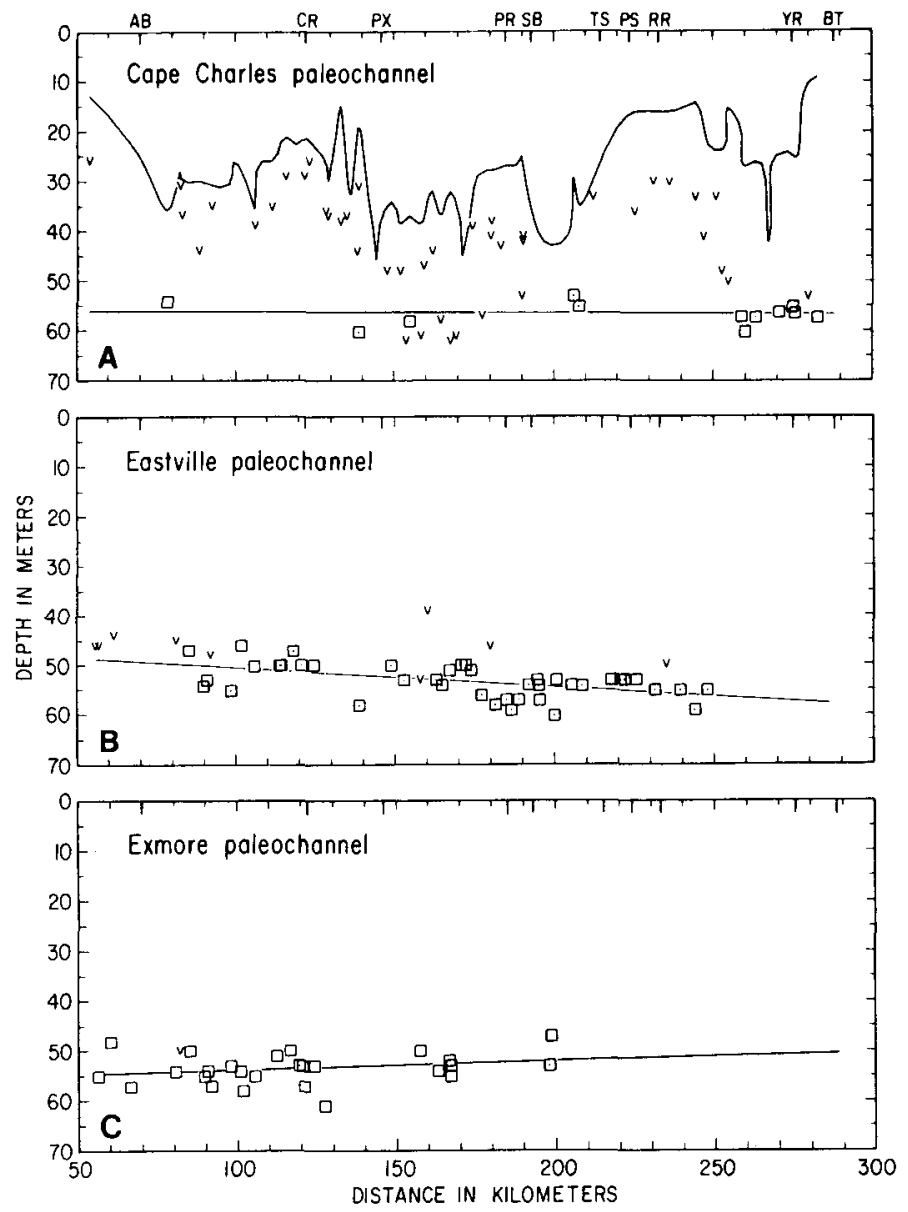

the river was $20 \mathrm{~m}$ deep at its mouth (the depth at its present mouth), then the base of the Cape Charles channel was at about $-105 \mathrm{~m}$ at the shelf edge (Fig. 11). This value implies a considerable steepening of the gradient of the fluvial profile between the mouth of the present Chesapeake Bay and the edge of the continental shelf: an average gradient of about $0.5 \mathrm{~m} / \mathrm{km}$.

High-resolution seismic reflection profiles have been collected on the shelf off the mouth of the Chesapeake Bay and the Delmarva Peninsula (Field and Duane, 1976; Dillon and Oldale, 1978), but the hard-packed surficial sand on the shelf hinders penetration by the high-resolution acoustic signals. As a result, no former channels of the Susquehanna River have been clearly identified or traced in the subsurface across the shelf. Swift and others (1972) traced a subtle topographic valley across the shelf from the mouth of the Chesapeake Bay to Norfolk Canyon; they suggested that this valley represented the retreat path of the former mouth of the river estuary. In contrast to the Susquehanna, the late Wisconsinan course of the Delaware River has been traced in some detail (Twichell and others, 1977). The Delaware has a gradient of less than
Figure 10. Longitudinal profiles of the Cape Charles (A), Eastville (B), and Exmore (C) paleochannels. Squares, depths (below mean sea level) measured from seismic reflection profiles; letter $v$ depicts minimum depths. Distance is measured from the present mouth of the Susquehanna River; line of section is shown in Figure 1. Depth of modern channel in the bay shown by solid line in A. Abbreviations: AB, Annapolis-Kent Island Bridge; CR, Choptank River; PX, Patuxent River; PR, Potomac River; SB, Maryland-Virginia state boundary; TS, mouth of Tangier Sound; PS, mouth of Pocomoke Sound; RR, Rappahannock River; YR, York River; and BT, Chesapeake Bay Bridge-Tunnel.

treme positions represent only minor parts of the cycle periods. As sea level falls, incision of the river would begin at the mouth and would tend to increase headward with time. If the duration of the lowstand were short, the river might not have time to develop an equilibrium, concaveupward profile; instead, a convex-upward profile such as that suggested for the lower course of the river in Figure 11 would indicate rapid sealevel changes and non-equilibrium conditions. This appears to be the case for tributaries of the Susquehanna River beneath the Chesapeake Bay, which have formed convex-upward profiles similar to that suggested for the Susquehanna River in Figure 11 in response to incision by the trunk stream (Hack, 1957). If sea-level fluctuations were cyclic and more rapid than the response of the river, then the middle section of the river (beneath the present Chesapeake Bay) might be expected to develop a profile that projects to the long-term mean sea-level position. The suggested profile for the Susquehanna beneath the Chesapeake Bay (Fig. 11) projects to about $-60 \mathrm{~m}$ at the shelf edge. This value compares to sea-level cycle extremes of zero for the present interglacial and $-85 \mathrm{~m}$ (Dillon and Oldale, 1978) to $-120 \pm 60 \mathrm{~m}$ (Bloom, 1983) for the last glacial maximum.

\section{AGES OF THE PALEOCHANNELS}

Evidence for the ages of the paleochannels comes from a variety of chronometric and stratigraphic data. The ages of the Cape Charles paleochannel and its fill are relatively well known by virtue of the fact that they represent the last sea-level cycle and because radiocarbon ages, ranging from about 8 to $15 \mathrm{ka}$ (Harrison and others, 1965; Meisburger, 1972), are available for the channel fill. The paleochannel has been correlated with marine oxygen-isotope stage 2 (Colman and Mixon, 1988), the peak of which occurred about $18 \mathrm{ka}$ (Imbrie and others, 1984; Martinson and others, 1987). The Cape Charles paleochannel is clearly related to the low-sea-level stand associated with the last 
Figure 11. Longitudinal profile of the ancestral Susquehanna River from its present mouth to the edge of the continental shelf. Distance is measured from the present mouth of the Susquehanna River; line of profile within the Chesapeake Bay is shown in Figure 1. Squares, Cape Charles paleochannel; circles, Eastville paleochannel; triangles, Exmore paleochannel. Open symbols are depths derived from seismic reflection profiles (Fig. 10), excluding minimum values; solid symbols represent depths derived from boreholes and an estimate of the base of the channel at the shelf edge (see text). Dashed line is an early estimate of the profile of the Susquehanna River (Hack, 1957); solid line is the generalized profile suggested here.

major glaciation, the late Wisconsinan, and has been only partly filled with sediment during the Holocene transgression.

Each of the two older paleochannels is assumed to correlate with an interval of low sea level of about the same magnitude as that of the late Wisconsinan glaciation and oxygen-isotope stage 2. Each of the older paleochannels is filled with estuarine sediments and overlain by barrier-spit deposits on the Delmarva Peninsula (Mixon, 1985). No major unconformities exist within these fill sequences (Colman and Mixon, 1988); local regressive unconformities exist only near or above present sea level on the Delmarva Peninsula. Therefore, each of the paleochannels is inferred to correlate with a major glaciation, immediately followed by a major interglaciation. These prominent transitions have been called "terminations" (Broecker and van Donk, 1970); the Cape Charles paleochannel and its Holocene fill represent termination I (Colman and Mixon, 1988). The barrier-spit deposits that conformably overlie the paleochannel fills on the Delmarva Peninsula represent the last events of the terminations and thus constrain the ages of the paleochannels. Ages of the terminations are tied to the dating of the marine oxygenisotope record (Imbrie and others, 1984; Martinson and others, 1987).

Uranium-series and uranium-trend analyses (Mixon and others, 1982; Szabo, 1985) and amino acid age estimates (Wehmiller and others, 1989) exist for the two ancient barrier systems on the Delmarva Peninsula. The ages of these and nearby deposits have been the subject of considerable discussion and argument, which have been reviewed in relation to the history of the bay by Colman and Mixon (1988). Uranium-series and amino acid age estimates

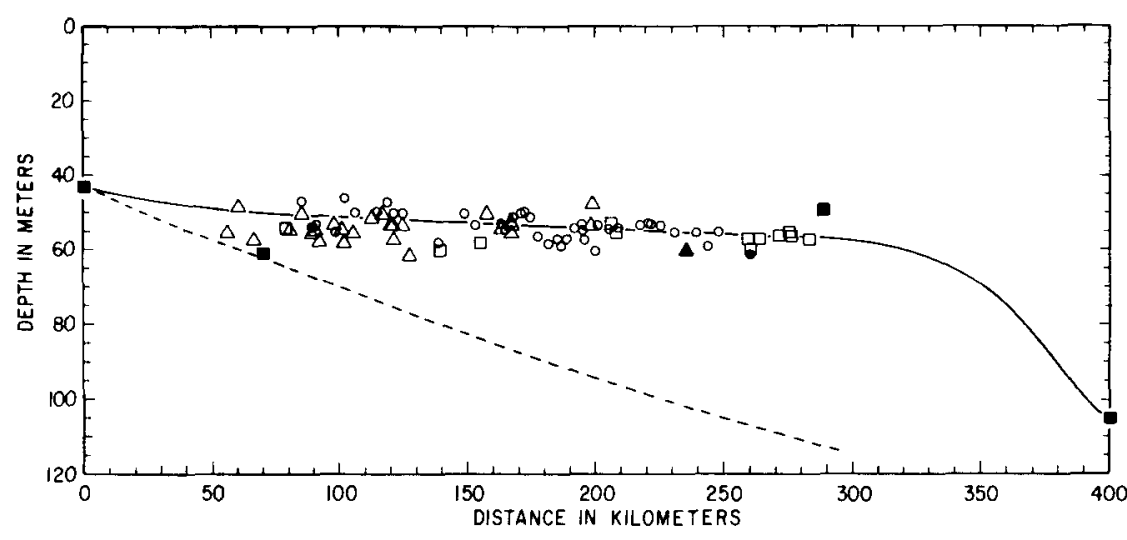

are incompatible in some cases; both methods conflict with stratigraphic interpretations in other cases; and some of the uranium-series age estimates do not closely correspond to known times of high sea level. Nevertheless, it appears that the barrier-spit that overlies the Eastville paleochannel correlates with the last major (Sangamon) interglaciation and with oxygenisotope stage 5, about $125 \mathrm{ka}$. Accordingly, the Eastville paleochannel presumably dates from oxygen-isotope stage 6 (Colman and Mixon, 1988), about $150 \mathrm{ka}$. The age of the barrier-spit that overlies the Exmore paleochannel is more problematic, but Colman and Mixon (1988) have suggested that these deposits may correlate with either oxygen isotope stage 7 (about 200 ka) or with stage 11 (about $400 \mathrm{ka}$ ). If so, the Exmore paleochannel likely correlates with stage 8 (about $270 \mathrm{ka}$ ) or stage 12 (about $430 \mathrm{ka}$ ).

\section{DISCUSSION AND IMPLICATIONS}

Deep paleochannels and their fills are prominent parts of the Quaternary geologic record in the Chesapeake Bay area. They represent a marked change from pre-Quaternary depositional patterns, in that the regional Tertiary stratigraphy shows no channels even approaching the size of those seen in the Quaternary. The Neogene strata in the area range in origin from fluvial-deltaic to nearshore marine (Owens and Denny, 1979; Owens and Minard, 1979; Peebles and others, 1984; Mixon, 1985; Ward and Strickland, 1985). Where these deposits are fluvial or fluvial-deltaic, they typically form sheets of sand or sandy gravel that contain abundant channel structures (Hack, 1955; Schlee, 1957; Owens and Denny, 1979; Owens and Minard, 1979). These relatively small channel structures, however, contrast markedly with the large, dis- crete paleochannels described here, which have relief of as much as $50 \mathrm{~m}$ and which are filled primarily with fine-grained estuarine sediments rather than with coarse sand or gravel. We suspect that this contrast is related to the inception of high-frequency, high-amplitude, sea-level fluctuations associated with continental glaciation. The earliest unit that occupies significant incised channels appears to be the Chowan River Formation of late Pliocene age (Blackwelder, 1981; Peebles and others, 1984), which is consistent with the estimate of $2.4 \mathrm{~m} . \mathrm{y}$. for the onset of North Atlantic ice-rafting (Shackleton and others, 1984). The oxygen-isotope record suggests that ice-volume and sea-level fluctuations were relatively small in amplitude and had a period of about $41,000 \mathrm{yr}$ in the latest Pliocene and early Pleistocene; a major increase in amplitude and period of the cycles occurred about 800-900 ka (Shackleton and Opdyke, 1976; Prell, 1982; Ruddiman and others, 1986). Large-amplitude sea-level and ice-volume fluctuations have occurred with a period of 100,000 yr since then; we correlate the three large Quaternary paleochannels identified here with three of the largest positive oxygen-isotope peaks (Colman and Mixon, 1988). The formation and filling of the paleochannels mark a major change in the style of estuarine sedimentation on the Atlantic continental margin. Large paleochannels identified in and near other estuaries (Hine and Snyder, 1985; Knebel and Circe, 1988) suggest that this change applies to the margin in general.

Our reconstruction of the three generations of paleochannels beneath the Chesapeake Bay area shows distinct spatial and temporal patterns. The channels diverge toward the southeast, and each channel is entirely to the west of its predecessor, with the single exception of a short segment of the Eastville channel off Calvert Cliffs 
(Fig. 8). Where the channels cross the Delmarva Peninsula, each channel is found progressively farther south than its predecessor.

This pattern reflects the southward progradation of the Delmarva Peninsula during major interglacial high sea-level stands (Colman and Mixon, 1988), the latest episode of which is evident in the late Holocene history of the bay mouth (Meisburger, 1972; Field and Duane, 1976; Colman and others, 1988). There, the modern spit complex is extending southward at about $12 \mathrm{~m}$ per year (Field and Duane, 1976), and the axial channel of the bay has been displaced as much as $12 \mathrm{~km}$ southward in the past few thousand years (Colman and others, 1988). This progradation of the peninsula and southward migration of the mouth of the bay is episodic, occurring only during the highest of interglacial sea-level stands (Colman and Mixon, 1988). During each major interglaciation, the former fluvial channel is filled with estuarine sediments throughout the bay, and the estuarine tidal channel migrates southward of the former fluvial channel at the bay mouth. As sea level falls following the interglaciation, the displaced estuarine channel becomes the new fluvial channel, the previous generation of the fluvial channel and its fill are preserved, and the course of the Susquehanna River is altered.

The many isolated segments of paleochannels identified by previous workers (Fig. 2) are incorporated into our reconstructions, and the spatial and age relationships among these segments are now clear. We recognize three distinct generations of the Susquehanna River, each of which forms a well-defined, integrated, fluvial system. Kehrin and others (1980) correctly inferred that the paleochannel in the lower Chester River, first identified by Schubel and Zabawa (1973), extends southward across the mouth of Eastern Bay and beneath the Poplar Island area. The channel does not turn eastward in the Choptank River nor connect with the Salisbury channel, as suggested by Schubel and Zabawa (1973). The Salisbury channel is not part of any of the paleochannel systems described here, and if it is truly a former course of the Susquehanna River, its position to the northeast of the Exmore paleochannel suggests that it is older than any of those we have identified.

Kehrin and others (1980) were also correct when they inferred that their channel, which we call the "Exmore paleochannel," extends beneath the Eastern Shore and into Tangier Sound. Instead of extending down the east side of Chesapeake Bay, however, the channel crosses the Delmarva Peninsula just south of the mouth of Tangier Sound. Beneath the Poplar
Island area, the Exmore and Eastville paleochannels partly overlap (Fig. 7), so that Kehrin and others (1980) actually saw two partly superimposed paleochannels instead of the single paleochannel they identified. Their inference of an Illinoian age for their channel was correct for the Eastville channel, but they mostly followed the Exmore channel, which is older.

The channel that Harrison (1972) inferred beneath Metomkin Island, on the basis of the distribution of reworked crystalline gravel along the modern beach, does not appear to relate to any other known paleochannel. It is well north of the Exmore paleochannel and well south of the Salisbury paleochannel (Fig. 2). If the gravels were derived from the Susquehanna or Potomac Rivers, the channel system that served as the conduit is unknown.

Mixon's (1985) map of the top of the Tertiary on the southern Delmarva Peninsula indicated that the channel beneath the town of Exmore was at only about $-24 \mathrm{~m}(-70 \mathrm{ft})$. Subsequent deepening of a critical borehole, however, has shown that the channel extends to depths of at least $-60 \mathrm{~m}(-200 \mathrm{ft})$ (R. B. Mixon and D. S. Powars, 1986, unpub. data; Colman and Mixon, 1988). These data and those for the Eastville paleochannel farther south on the Delmarva Peninsula, along with the stratigraphic relationships between the paleochannels and the barrierspit complexes on the Delmarva Peninsula (Mixon, 1985), form the basis for our reconstruction of the history of the paleochannel systems (Colman and Mixon, 1988).

The suggestion by Harrison and others (1965) that the mouth of Chesapeake Bay has been uplifted by as much as $52 \mathrm{~m}(170 \mathrm{ft})$ since late Wisconsinan time has long been controversial. This amount of uplift was inferred from the difference between the altitude of the paleochannel beneath the Annapolis-Kent Island Bridge $(-60 \mathrm{~m},-200 \mathrm{ft})$ and that derived from Hack's (1957) estimated channel gradient, projected to the bay mouth $(-112 \mathrm{~m},-370 \mathrm{ft})$. The actual base of the channel is an additional $12 \mathrm{~m}$ higher at the mouth of the bay than at the AnnapolisKent Island Bridge. Many of the objections to this hypothesis disputed the interpretation that the channels beneath the Annapolis-Kent Island Bridge and the Bay Bridge-Tunnel were the same channel; rather, it was suggested (Harrison, 1972) that the channel of the Susquehanna River beneath the Kent Island Bridge probably crossed the southern Delmarva Peninsula and that the channel beneath the Bay Bridge-Tunnel was a tributary. Our seismic reflection data, however, show that the channel segments beneath the two structures are unequivocally the same channel and the same age (late Wisconsinan).

Nevertheless, no uplift of the bay mouth is required to explain the fact that the base of the channel is $12 \mathrm{~m}$ higher at the mouth of the bay than at a point $220 \mathrm{~km}$ upstream. The water surface of the ancient river must have sloped seaward, but segments of the base of the channel need not have, especially because the channel tends to increase in width downstream. The variability of the depth to the base of the Cape Charles paleochannel (Fig. 10A) easily accommodates the 12-m difference. The Cape Charles paleochannel can be traced nearly continuously from the Annapolis-Kent Island Bridge to the Chesapeake Bay Bridge-Tunnel, and it and the two older paleochannels all have irregular longitudinal profiles and extremely low gradients within the bay (Figs. 10 and 11).

The spatial and temporal pattern of the paleochannels indicates that they have been migrating westward through time. The root cause of this migration has been the migration of the mouth of the Chesapeake Bay southward during interglacial periods (Colman and Mixon, 1988). The morphology of the bay, like that of all coastalplain estuaries, depends on the fluvial erosion preceding the marine transgression that formed the estuary. Thus, the configuration of each generation of Chesapeake Bay has changed dramatically as the paleochannels have migrated westward. A consequence of these changes is that the erosion surface on top of the Tertiary is younger on the west side of the bay than it is on the east side. In addition, the islands and parts of the Eastern Shore that overlie the paleochannels and the southern part of the Delmarva Peninsula are all geologically young, younger than the Eastville or Exmore paleochannels. The dramatic changes that have occurred in the Chesapeake Bay area therefore indicate a dynamic and changing geological environment on the Atlantic coastal plain. This dynamic environment will result in major bathymetric and coastline changes as sea-level rise continues or accelerates, and it will result in a new course for the Susquehanna River when sea level next falls.

\section{ACKNOWLEDGMENTS}

We thank the captains and crews of the R.V. Discovery, R.V. Langley, and R.V. Dan Moore for their cooperation. The staff of the U.S. Geological Survey, Woods Hole, helped with data collection and processing of the manuscript. J. C. Kraft, J. E. Pizzuto, J. S. Schlee, and D. C. Twichell provided helpful reviews of earlier versions of the paper. 


\section{REFERENCES CITED}

Blackwelder. B. W., 1981, Stratigraphy of upper Ptiocene and lower Pleistocene marine and estuarine deposits of northeastern North Carolina and marine and estuarine deposits of northeastern North Carolina and
southeastern Virginia: U.S. Geological Survey Bulletin 1052-B, 16 p.

southeastern Virginia: U.S. Geological Survey Bulletin $1052-B, 16$ p.
Bioom, A. L., 1983, Sea level and coastal changes, in Wright, H. E., Jr., ed., Late Quaternary environments of the United States, Volume 2, The Late Quaternary environments of the United States, Volume 2, The
Holocene: Minneapolis, Minnesola, University of Minnesota Press, polocene:

Broecker, W. S., and Van Donk, Jan, 1970. Insolation changes, ice volumes and the $O^{18}$ record in deep-sea cores: Reviews of Geophysics and Space Physics, v. 8, p. 169-198.

Carson, Michael, 1979, The Virginia Chesapeake Bay-Recent sedimentation and paleodrainage [Ph.D. dissert.]: Gloucester Point, Virginia, Virginia Institute of Marine Science, College of William and Mary, $83 p$

Colman, S. M., and Halka, J. P.. 1989a, Quaternary geology of the southern Maryland part of the Chesapeake Bay. U.S. Geological Survey Miscellaneous Field Studies Map MF-1948-C.

- 1989b, Quaternary geology of the northern Maryland part of the Chesapeake Bay: U.S. Geological Survey Miscellaneous Field Studies Map MF-1948-D

Colman, S. M., and Hobbs, C. H., III, 1987, Quaternary geology of the southern Virginia part of the Chesapeake Bay: U.S. Geological Survey Miscellaneous Field Studies Map MF-1948-A.

1988. Quaternary geology of the northern Virginia part of the Chesapeake Bay: U.S. Geological Survey Miscellaneous Field Studies Map MF-1948-B.

Colman, S. M., and Mixon, R. B., 1988, The record of major Quaternary sea-level fluctuations in a large Coastal Plain estuary, Chesapeake Bay, eastern United States: Palaeogeography, Palaeoclimatology, and Palaeoecology, v. 68, p. 99-116.

Colman, S. M., Berquist, C. R., Jr., and Hobbs, C. H., III, 1988, Structure, age, and onigin of the deposits beneath the shoals at the mouth of Chesapeak Bay, Virginia: Marine Geology, v. 83, p. $95-113$.

Dillon, W. P., and Oldale, R. N., 1978, Late Quaternary sea-level curveReinterpretation based on glaciotectonic influence: Geology, v. 6 , p. $56-60$.

Ewing, John, Le Pichon, Xavier, and Ewing, Maurice, 1963, Upper stratification of Hudson apron region: Journal of Geophysical Research, y. 68 p. 6303-6316

Field, M. E., and Duane, D. B., 1976, Post-Pleistocene history of the United States inner continental shelf-Significance to the origin of barrier islands: Geological Sociaty of America Bulletin v. 87, 691-702.

Hack, J. T., 1955, Geology of the Brandywine area and origin of the upland of southern Maryland: U.S. Geological Survey Professional Paper 267-A p. 143.

1957, Submerged river system of Chesapeake Bay: Geological Society of America Bulletin, v. 68, p. 817-830.

Halka, J. P.. Hill, J. M., and Colman, S. M., 1988, Control of methane gas ebullition from estuarine sediments by paleodrainage patterns: EOS (American Geophysical Union Transactions), v. 69, p. 379.

Hansen, H. J., III, 1966, Pieistocene stratigraphy of the Salisbury area, Maryland, and its relation to the lower Eastern Shore-A subsurface approach: Maryland Geological Survey Report of Investigations No. 2 $56 \mathrm{p}$
Harrison, S. C., 1972, The sediments and sedimentary processes of the Holocene tidal flat complex, Delmarva Peninsula, Virginia: Baton Rouge Louisiana Louisiana State University Coasta Studies Institute Technical Report 112, 107 p.

Harrison, W., Malloy, R. J., Rusnak, G. A., and Terasmae, J., 1965, Possible late Pleistocene uplift, Chesapeake Bay entrance: Journal of Geology, v. 73, no. 2, p. 201-229.

Hays, J. D., Imbrie, J., and Shackleton, N. J., 1976, Variations in the Earth's orbit-Pacemaker of the ice ages: Science, v. 194, p. 1121-1132.

Hine, A. C., and Snyder, S. W., 1985, Coastal hithosome preservationEvidence from the shoreface and inner continental shelf off Boque Evidence from the shoreface and inner continental shelf
Banks, Nonh Carolina: Marine Geology, v. 63, p. 307-330.

Imbrie, John, Hays, J. D., Martinson, D. G., McIntyre, A., Mix, A. C., Morley, J. J., Pisias, N. G., Prell, W. L., and Shackleton, N. J., 1984, The orbital J. J., Pisias, N. G., Prell, W. L., and Shackleton, N.J., 1984, The orbital theory of Pleistocene climate--Support from a revised chronology of
the marine ${ }^{18} \mathrm{O}$ record, in Berger, A. L., and others, eds., Milankovitch the manne ${ }^{\prime} \mathrm{O}$ record, in Berger, A. L., and others, eds., Milankovitch and climate. $269-305$.

Kehrin, R. T., Halka, J. P., and Conkwright, R. D., 1980, Identification of a paleochannel system under the eastern flank of Chesapeake Bay: Geological Society of America Abstracts with Programs, v. 12, p. 461.

Knebel, H. J., and Circe, R. C., 1988, Late Pleistocene drainage systems beneath Delaware Bay: Marine Geology, v. 78, p. 285-302.

Martinson, D. G., Pisias, N. G., Hays, J. D., Imbrie, J., Moore, T. C., Jr., and Shackleton, N. J., 1987, Age dating and the orbital theory of the ice ages-Development of a high-resolution 0 to 300,000-year chronostratigraphy: Quaternary Research, v. 27, p. 1-29.

Meisburger, E. P., 1972, Geomorphology and sediments of the Chesapeake Bay entrance: U.S. Army Corps of Engineers Coastal Engineering Research Center Technical Memorandum No. $38,61 \mathrm{p}$.

Mixon, R. B., 1985, Stratigraphic and geomorphic framework of uppermos Cenozoic deposits in the southern Delmarva Peninsula, Virginia and Maryland: U.S. Geological Survey Professional Paper 1067.G. 53 p.

Mixon, R. B., Szabo, B. J., and Owens, J. P., 1982, Uranium-series dating of molluscs and corals, and age of Pleistocene deposits, Chesapeake Bay area, Virginia and Maryland: U.S. Geological Survey Professional Paper 1067-E, $18 \mathrm{p}$

Owens, J. P., and Denny, C. S., 1979, Upper Cenozoic deposits of the upper Delmarva Peninsula, Maryland and Delaware: U.S. Geological Survey Professional Paper 1067-A, 28 p.

Owens, J. P., and Minard, J. P., 1979, Upper Cenozoic sediments of the lower Delaware Valley and the northern Delmarva Peninsula, New Jersey, Pennsylvania, Delaware, and Maryland: U.S. Geological Survey Pernsylvania, Delaware, and
Professional Paper 1067-D, 47 p.

Peebles, P. C. Johnson, G. H., and Berquist, C. R., 1984, The middle and tate Pleistocene stratigraphy of the outer coastal plain, southeastern Virginia: Virginia Minerals, v. 30 , no. 2, p. 13-22.

Prell, W. L., 1982, Oxygen and carbon isotope stratigraphy for the Quaternary of Hole 502B-Evidence for two modes of isotopic variability, in Prell, of Hole 502B-Evidence for two modes of isotopic variability, in Prell, Driling Project, Volume 68: Washington, D.C., U.S. Government Printing Office, p. 455-464.

Ruddiman, W. F., Raymo, M., and Mcintyre, A., 1986, Matuyama 41,000year cycles - North Atiantic Ocean and Northern Hemisphere ice year cycles - North Atiantic Ocean and Northern Hemisp.
sheets: Earth and Planetary Science Letters, v. 80, p. 117-129.
Ryan, J. D., 1953, The sediments of Chesapeake Bay: Maryland Department of Geology Mines, and Water Resources Bulletin 12, 120 p.

Schlee, John, 1957, Upland gravels of southern Maryland: Geological Society of America Bulletin, v. 68, no. 10, p. 1371-1410.

Schubel, J. R. and Zabawa, C. F., 1973, Susquehanna River paleochannel consects lower reaches of Chester, $M$

Shackleton, N. J, and Opdyke, N. D., 1976, Oxygen isotope and paleomage netic stratigraphy of Pacific core V28-239 late Pliocene to larest Pleistonetic stratigraphy on Cline, $\mathrm{R}$. Quaternary pateoceanography and paleoclimatology: Geological SoQuaternary pateoceanography and paleoctime

Shackleton N. J Backman J and others. 1984, Oxyeer isotope calibration of the onset of ice-rafting and history of glaciation in the North Atlantic region: Nature, v. 307 , p. $620-623$.

Shideler, G. L Ludwick, J. C Oertel, G. F and Finkelstein, K., 1984 Quatemary stratigraphic evolution of the southem Delmarva Peninsula coastal zone, Cape Charles, Virginia: Geological Society of America Bulletin, v. 95 , no. 4, p. $489-502$

Swift, D.J. P. Kofoed, W Saulsbury, F. P., and Sears, P., 1972, Holocene evolution of the shelf surface, central and southern Atlantic shelf of North America, in Swift, D.J.P., Duane, D. P., and Pilkey, O. H., eds. Shelf sediment transport-Processes and pattern: Stroudsberg, Pennsylvania, Dowden, Hutchinson and Ross, p. 499-574.

Szabo, B. J., 1985, Uranium-series dating of fossil corals from marine sediment of southeastem United States Atlantic coas tal plain: Geological Society of America Bulletin, v. 96, no. 3, p. 398-406.

Twichell, D. C., Knebel, H. J., and Folger, D. W., 1977, Delaware RiverEvidence for its former extension to Wilmington Submarine Canyon Science, v. 195, p. 483

Ward, L. W., and Strickland, G. L., 1985, Outline of Tertiary stratigraphy and depositional history of the U.S. Atlantic Coastal Ptain, in Poag, C. W. ed., Geological evolution of the United States Atlantic margin: New York, Van Nostrand Reinhold Co., p. 87-123.

Wekmiller, J. F., Belknap. D. F, Boutin, B. S., Mirecki, J. E., Rahaim, S. D and York, L. L., 1989, A review of the amin ostratigraphy of Quaternary mollusks from United States Atlantic Coastal Ptain sites, in Easterbrook, D. L., ed. Dating Quaternary sediments: Geological Society of America Special Paper 227, p. 69-110.

Weigle, J. M., 1972. Exploration and mapping of the Salisbury paleochanne Wicomico County Maryland: Maryland Geol ogical Society Bulletin 31, Part 2, p. 61-123.

Manuschipt ReCenved by the Society June 5, 1989 Revised Manuscript Received Janiaty 17,1990 REVISED MANUSCRIPT RECEIVED JANUARY

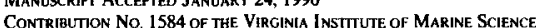

